\title{
RESIDIVIS ANAK SEBAGAI AKIBAT DARI RENDAHNYA KESIAPAN ANAK DIDIK LEMBAGA PEMASYARAKATAN DALAM MENGHADAPI PROSES INTEGRASI KE DALAM MASYARAKAT
}

\author{
Oleh: \\ Dyana C. Jatnika, Nandang Mulyana, \& Santoso Tri Raharjo
}

Email: dyanacjatnika@gmail.com, mulyananandang@yahoo.com, santosotriraharjo@gmail.com

\begin{abstract}
ABSTRAK Anak didik lembaga pemasyarakatan merupakan anak berhadapan dengan hukum yang harus menjalani masa tahanan dalam sebuah proses pembinaan di Lembaga Pemasyarakatan Anak. Problematika yang dihadapi saat ini adalah banyaknya kasus kenakalan anak dengan pelaku adalah mantan narapidana anak yang bersifat residivis. Residivis anak adalah mantan narapidana anak yang melakukan kembali tindak kejahatan serupa dalam masyarakat atau disebut sebagai penjahat kambuhan. Penyebab dari adanya residivis anak adalah rendahnya kesiapan anak didik lembaga pemasyarakatan dalam menghadapi proses integrasi ke dalam masyarakat oleh karena pembinaan di Lembaga Pemasyarakatan Anak yang kurang efektif dan tidak terintegrasi dengan kehidupan bermasyarakat. Penelitian ini bertujuan untuk mengetahui kesiapan anak didik lembaga pemasyarakatan, baik secara fisik, mental, maupun sosial dalam menghadapi proses integrasi ke dalam masyarakat. Subyek penelitian adalah anak didik lembaga pemasyarakatan yang sedang menjalani $1 / 3$ sisa masa tahanan. Metode yang digunakan dalam penelitian ini adalah metode penelitian atas dasar studi kepustakaan. Hasil penelitian menunjukkan bahwa akibat dari rendahnya kesiapan anak didik lembaga pemasyarakatan dalam menghadapi proses integrasi ke dalam masyarakat adalah kasus residivis anak. Kesiapan anak dapat ditinjau berdasarkan jenis pembinaan fisik, mental, dan sosial yang dilaksanakan di Lembaga Pemasyarakatan Anak. Rendahnya kesiapan anak didik lembaga pemasyarakatan disebabkan oleh pembinaan di Lembaga Pemasyarakatan Anak yang kurang efektif. Adapun kebutuhan anak didik lembaga pemasyarakatan menjelang masa kebebasan dalam kehidupan bermasyarakat diantaranya adalah kebutuhan sosialisasi yang memungkinkan dirinya untuk mendapatkan kembali pemenuhan hak dan kebutuhan sebagai seorang warga negara.
\end{abstract}

ABSTRACT The punishment that a child would get if they do something against the rule is that they will be labelled as children prisoners or children who are under penitentiary control. The existing problem is the huge number of deliquency cases with the recidivist children prisoners as the actors. Recidivist case or an act of former children prisoners who continuously commit crimes that make them go back to the penitentiary is one of impacts of their powerless selves to face the society's rejection. It is caused by the inefectivity and unintegrated of the skill development programme held by the Children Penitentiary that unable them to be confidently facing the society life. This study aims to determine the readiness of children prisoners both physically, mentally, and socially to dealing with process of society integration. The readiness of children prisoners is related to physical, mental, and social preparation during in Children Penitentiary. The subject of this research is Anak Didik Lapas or children prisoners who have been doing 1/3 the remaining period of detention. The method used in this research is the study of literature. The results shows that the effect of less readiness of children prisoners in facing of the process of society integration is the case of recidivist child. The 
readiness of the child can be evaluated based on physical, mental, and social training programmes that held by Children Penintetiary. The low readiness of children prisoners is caused by coaching in Children Penitentiary that are less effective. The Children Prisoners' need to facing the society integration after they released from Children Penitentiary is socialization need as an effort to make them as a good citizen in dealing with their needs and rights among the society.

\section{PENDAHULUAN}

Eksistensi generasi muda di Indonesia berpengaruh besar tehadap keberlangsungan pembangunan nasional yang berlandaskan kepada kemandirian dan kepribadian bangsa. Generasi muda adalah bagian dari harapan pemerintah dalam menjalankan upaya restorasi sosial sebagaimana yang dikemukakan dalam salah satu misi dari kepemimpinan Presiden Republik Indonesia saat ini, Jokowi Dodo, untuk memperbaiki kembali berbagai penyimpangan dari norma yang diharapkan oleh masyarakat. Namun, pada kenyataannya Indonesia memiliki jumlah kasus kenakalan remaja yang cukup tinggi dengan jumlah 2.716 narapidana anak (Direktorat Jenderal Pemasyarakatan, 2015).

Menurut Badan Penanggulangan Kenakalan Remaja dan Penyalahgunaan Narkotika Sumatera (Gultom, 2008), kenakalan remaja merupakan salah satu bentuk kelainan tingkah laku, perbuatan, ataupun tindakan remaja yang bersifat asosial, bertentangan dengan agama, dan hukum yang berlaku dalam masyarakat setempat. Pelanggaran tersebut akan menyebabkan anak nakal menyandang status sebagai Narapidana Anak atau menjadi anak didik lembaga pemasyarakatan (Andikpas). Berdasarkan Undang-Undang No. 12 Tahun 1995 tentang Pemasyarakatan, pembinaan bagi narapidana anak dilakukan sesuai dengan konsep pemasyarakatan dengan tujuan untuk memberikan bimbingan kepada anak didik lembaga pemasyarakatan agar menyadari kesalahannya, memperbaiki diri, dan tidak mengulangi tindak pidana di kemudian hari dengan harapan anak dapat diterima kembali di lingkungan masyarakat serta dapat menjalankan status dan perannya sebagai warga negara yang bertanggungjawab dan aktif dalam pembangunan.
Namun, problematika yang dihadapi saat ini adalah banyaknya kasus kenakalan remaja dengan pelaku adalah mantan narapidana anak yang bersifat residivis. Residivis terjadi ketika mantan narapidana anak belum memiliki kesiapan penuh dalam menghadapi proses integrasi ke dalam masyarakat. Komisi Nasional untuk Anak (2011) melaporkan bahwa angka pelaporan anak berhadapan dengan hukum sebanyak 52\% didominasi oleh kasus pencurian, kemudian diikuti dengan kasus lainnya seperti narkoba, perlindungan terhadap anak, pelanggaran tertib berlalu lintas, perampokan, dan pembunuhan. Akan tetapi, berdasarkan data dari Jurnal Harian Lembaga Pemasyarakatan Anak Kelas III Bandung per Maret 2015, kasus narapidana anak pada kasus pencurian sebanyak $42,8 \%$ adalah pelaku residivis. Fenomena ini membuktikan bahwa kekhawatiran masyarakat akan residivis narapidana anak (Marlina, 2009) adalah benar adanya. Kembalinya seorang mantan narapidana anak ke Lembaga Pemasyarakatan Anak atau yang dapat disebut sebagai residivis merupakan salah satu dampak dari adanya ketidaksiapan dalam diri mantan narapidana anak sehingga mengulangi tindak kejahatan serupa sebagai penjahat kambuhan di masyarakat.

Salah satu penyebab rendahnya kesiapan mantan narapidana anak untuk bersosialisasi kembali adalah proses pembinaan di Lembaga Pemasyarakatan Anak yang belum efektif. Berdasarkan hasil penelitian yang dilakukan oleh Artyawan (2013), penyelenggaraan program pendidikan keterampilan di Lembaga Pemasyarakatan hanya memberikan kontribusi terhadap kesiapan narapidana kembali ke masyarakat hanya sebesar $44,7 \%$. Salah satu penyebab dari pembinaan yang kurang efektif adalah tidak terintegrasinya proses pembinaan dengan kehidupan bermasyarakat. Pembinaan 
fisik, mental, dan sosial di Lembaga Pemasyarakatan Anak tidak cukup untuk memberikan kepercayaan diri atas kesiapan anak didik lapas menuju proses integrasi ke dalam masyarakat.

Menurut Gultom (2008), dalam menangani permasalahan mantan narapidana anak, diperlukan suatu upaya untuk meningkatkan kesadaran publik bahwa perhatian terhadap anak dan mempersiapkan anak kembali ke masyarakat adalah satu bentuk pelayanan sosial yang sangat penting. Oleh karena itu, perlu diambil langkah-langkah tertentu untuk membuka hubungan antara anak dengan masyarakat. Sosialisasi bagi mantan narapidana anak dapat dikatakan sebagai sebuah proses adaptasi diri kembali dalam kehidupan bermasyarakat. Kebutuhan akan proses sosialisasi seorang remaja dalam upaya pemenuhan kebutuhan juga dipengaruhi oleh keadaan lingkungan sosial, terlebih apabila lingkungan keluarga dan masyarakat sudah tidak bisa menerima keberadaan dirinya kembali seperti sebelumnya. Berdasarkan penjelasan tersebut, penulis terdorong untuk mengkaji lebih jauh mengenai kesiapan anak didik lapas dalam menghadapi proses integrasi ke dalam masyarakat salah satu penyebab dari kasus residivis anak di masyarakat.

\section{Metode Penulisan}

Metode yang digunakan dalam penulisan karya tulis ilmiah ini adalah metode penelitian deskriptif. Metode yang digunakan untuk mengumpulkan data adalah metode studi pustaka yang terdiri atas pencarian data dan informasi melalui dokumen-dokumen pendukung berupa data dari buku, jurnal ilmiah, dan dokumen elektronik dari internet. Adapun tahapan dalam penulisan diantaranya perumusan masalah untuk kemudian menjadi gagasan, pengumpulan data dan fakta terkait, verifikasi data dan fakta, analisa konseptual dengan argumentasi yang rasional, perumusan hasil gagasan dan kesimpulan serta rekomendasi terkait penanganan masalah.

\section{PUSTAKA}

\section{Kenakalan Remaja}

Kenakalan anak atau Juvenile Delinquency dapat diartikan sebagai bagian dari bentuk penyimpangan perilaku terhadap hukum atas norma dan nilai yang berlaku di masyarakat dengan status dan peran sosial pelaku adalah anak. Anak yang beresiko memiliki kemungkinan berperilaku menyimpang berada dalam keadaan yang sulit. Berdasarkan laporan dari Jurnal Harian Lembaga Pemasyarakatan Anak Kelas III Bandung, mayoritas anak didik lembaga pemasyarakatan berusia 16-18 tahun atau berada pada usia remaja.

Menurut Gultom (2008), kenakalan remaja dirumuskan sebagai suatu kelainan tingkah laku, perbuatan ataupun tindakan remaja yang bersifat asosial, bertentangan dengan agama, dan ketentuan-ketentuan hukum yang berlaku dalam masyarakat. Dalam hal ini, kenakalan remaja akan terkait dengan bentuk perilaku menyimpang dan lingkungan sosial yang membentuknya.

Melalui penelaahan lebih lanjut, maka kenakalan remaja merupakan salah satu akibat dari adanya ketimpangan dalam lingkungan sosial yang membentuknya. Loeber (2013) dalam karyanya yang berjudul From Juvenile Delinquency to Young menyampaikan bahwa salah satu proses yang membentuk anak atau remaja untuk melakukan perbuatan menyimpang diantaranya faktor pendorong dan resiko sosial yang meliputi lingkungan keluarga, sekolah, dan teman sebaya. Untuk menangani hal ini, Loeber menyampaikan bahwa diperlukan suatu upaya assesment lebih lanjut mengenai kebutuhan dan resiko remaja serta rencana intervensi dalam memperbaiki remaja dengan perilaku menyimpang.

Anak dengan perilaku menyimpang yang melanggar hukum akan dikenai sanksi dengan menyandang status sebagai Anak Didik Lembaga Pemasyarakatan (Andikpas). Pembinaan yang diselenggarakan di Lembaga Pemasyarakatan Anak bertujuan untuk memberikan bimbingan pelatihan, kepribadian, dan keagamaan dengan tujuan agar anak didik lapas dapat menyadari 
kesalahannya dan tidak mengulangi lagi setelah kembali ke masyarakat. Dalam hal ini, pemikiran Loeber selaras dengan Seiter, Kadela (2003) dalam karyanya yang berjudul Prisoner Reentry: What Works, What Does Not, and What Is Promising. Seiter, Kadela (2003) mengemukakan bahwa ada dunia yang akan dimasuki oleh mantan narapidana. Walaupun pembinaan yang diberikan di Lembaga Pemasyarakatan bertujuan untuk memberikan kesiapan fisik, mental, dan sosial kepada anak didik lembaga pemasyarakatan, namun hal ini terpisah dari 'dunia' yang akan dihadapinya secara nyata setelah keluar dari Lembaga Pemasyarakatan Anak. Dukungan keluarga, sumber daya dalam kehidupan bermasyarakat, dan kesediaan dukungan moral dari masyarakat menjadi hal yang berbeda dan mempengaruhi proses reintegrasi mantan narapidana anak di tengah kehidupan bermasyarakat. Pemikiran ini sangat relevan dengan salah satu laporan ilmiah dari The Pew Charitable Trusts tentang The Rise in Prison Inmates Released Without Supervision (2014), bahwa walaupun ada pembinaan dan pengawasan setelah narapidana keluar dari lembaga pemasyarakatan, namun belum menjamin efektivitas pengurangan jumlah residivis.

\section{Residivis Anak}

Indonesia memiliki jumlah kasus kenakalan remaja yang cukup tinggi dengan jumlah narapidana anak sebanyak 2.716 anak. Jawa Barat merupakan provinsi kedua tertinggi setelah Sumatera Utara yang memiliki jumlah anak pidana terbanyak di Indonesia. Anak Pidana atau Anak Berhadapan dengan Hukum $(\mathrm{ABH})$ ditangani dalam sebuah pembinaan di Lembaga Pemasyarakatan dan Balai Pemasyarakatan selepas keluar dari Lembaga Pemasyarakatan Anak.

Kembalinya seorang mantan narapidana anak ke Lembaga Pemasyarakatan Anak atau yang dapat disebut sebagai residivis merupakan salah satu dampak dari adanya ketidakberdayaan dalam diri seorang mantan narapidana anak untuk bersosialisasi kembali dalam masyarakat sebagai seorang remaja yang bertanggungjawab di tengah pandangan negatif masyarakat terhadap dirinya. Menurut Seiter, Kadela dalam sebuah penelitian yang berjudul Prisoner Reentry: What Works, What Does Not, and What Is Promising (2003), mengemukakan bahwa hal utama yang perlu diperhatikan dari keberadaan mantan narapidana adalah adanya pengawasan dari masyarakat dalam bentuk stabilitas dukungan dan pelayanan sosial yang khusus diberikan kepadanya dalam bentuk program ataupun aktivitas yang memungkinkan mantan narapidana tidak menjadi residivis. Hal ini selaras dengan fokus dari pembinaan di lembaga pemasyarakatan anak yang didasarkan atas konsep pemasyarakatan dengan tujuan mempersiapkan anak didik lembaga pemasyarakatan agar diterima kembali dalam kehidupan bermasyarakat.

Residivis anak adalah mantan narapidana anak yang selepas keluar dari lembaga pemasyarakatan melakukan tindak kejahatan kembali serupa atau disebut sebagai penjahat kambuhan. Berdasarkan data primer yang diperoleh dari Jurnal Harian Lembaga Pemasyarakatan Anak Kelas III Bandung, diketahui bahwa 42,8\% penghuni Lembaga Pemasyarakatan Anak per Bulan Maret 2015 pada salah satu kasus, yaitu kasus pencurian, adalah narapidana anak residivis. Hal ini membuktikan bahwa kekhawatiran masyarakat akan penilaian atau stigmatisasi terhadap anak residivis (Marlina, 2009) adalah benar adanya.

Berdasarkan kepada fenomena tersebut, maka pandangan atau penolakan yang berupa stigmatisasi dari masyarakat terhadap mantan narapidana anak masih berlaku. Ketidakberdayaan mantan narapidana anak untuk kembali ke lingkungan sosialnya sebagaimana ia diterima dahulu menjadi salah satu hal yang dapat menjadi stressor baginya untuk kemudian dilampiaskan kembali dalam bentuk perilaku menyimpang. Aksesibilitas yang minim terhadap pemenuhan hak sebagai seorang warga negara merupakan salah satu dampak dari ketidakberdayaan masyarakat dalam memberikan kepercayaan 
kembali kepada mantan narapidana anak untuk menjalankan perannya sebagai seorang remaja dan warga negara.

Pembinaan bagi Anak Didik Lembaga Pemasyarakatan

Pembinaan bagi anak didik lembaga pemasyarakatan pada dasarnya dijalankan atas konsep pemasyarakatan. Pembinaan juga difokuskan pada tiga hal utama, yaitu pembinaan fisik, mental, dan sosial. Ada empat komponen penting dalam prinsip pembinaan narapidana, diantaranya:

\section{Diri Sendiri}

Pembinaan yang ada di Lembaga Pemasyarakatan Anak harus dilaksanakan atas dasar kemauan dari anak didik lembaga pemasyarakatan untuk melakukan suatu perubahan terhadap dirinya ke arah yang lebih positif. Beberapa hal yang perlu dimiliki oleh seseorang jika ingin melakukan perubahan diantaranya: kemauan, kepercayaan diri, berani mengambil keputusan, berani menanggung resiko, dan termotivasi untuk merubah dirinya.

Hal tersebut adalah penting mengingat anak didik lembaga pemasyarakatan sedang menjalani masa pembinaan dengan konsep pemasyarakatan, sehingga upaya untuk mengenal diri sendiri sebagai langkah awal perubahan dapat terlaksana atas dasar pengambilan keputusan dirinya sendiri.

\section{Keluarga}

Keluarga merupakan lingkungan primer bagi anak didik lembaga pemasyarakatan. Hubungan yang harmonis dengan keluarga diteliti dapat mengurangi jumlah kenakalan remaja (Gultom, 2008). Sehingga, dalam hal ini keluarga memiliki peran penting bagi proses perubahan diri bagi anak didik lembaga pemasyarakatan.

Hubungan yang harmonis dapat terjaga dengan adanya kunjungan keluarga. Kualitas dan kuantitas kunjungan keluarga bagi pembinaan sosial anak didik lembaga pemasyarakatan seyogyanya diperhatikan oleh lembaga pemasyarakatan anak dalam rangka meningkatkan kesiapan anak didik lembaga pemasyarakatan untuk kembali ke kehidupan bermasyarakat atas dasar asuhan dari keluarga sebagai lingkungan primer. Kunjungan keluarga juga merupakan salah satu upaya mencegah adanya kasus residivis anak atau kembalinya anak ke lembaga pemasyarakatan karena melakukan tindak kejahatan serupa kembali oleh karena adanya penolakan dari lingkungan sosial dirinya, salah satunya keluarga.

\section{Masyarakat}

Tujuan dari pembinaan yang didasarkan atas konsep pemasyarakatan adalah untuk memberikan bimbingan kepada anak didik lembaga pemasyarakatan agar menyadari kesalahan, memperbaiki sikap, tidak mengulangi tindak kejahatan lagi sehingga diharapkan dapat diterima kembali dalam kehidupan bermasyarakat. Namun, Alexander (2013) mengemukakan bahwa mantan narapidana akan menghadapi kemungkinan kurang berhasilnya untuk masuk kembali dalam kehidupan bermasyarakat oleh karena aksesibilitas yang rendah dalam bidang pendidikan, pelatihan, dan dukungan moral dari keberadaan keluarga dan kerabat.

Atas dasar penelaahan lebih lanjut, keadaan mantan narapidana saat ini belum mendapatkan penerimaan dan dukungan sosial penuh dari masyarakat terhadap keberadaan dirinya. Anderson (1990) mengemukakan bahwa kondisi mantan narapidana dalam kehidupan bermasyarakat akan terhambat oleh karena disorganisasi dalam keluarga dan masyarakat serta ketidaktersediaan sumber daya yang mendukung terhadap pemenuhan kebutuhan dan hak bagi dirinya.

Wilkinson (2001) mengemukakan salah satu contoh program reintegrasi di Ohio pada tahun 1985. Hal yang kemudian difokuskan dalam upaya kuratif dan preventif bagi penanganan kenakalan remaja diantaranya program lanjutan dari hasil pembinaan di 
Lembaga Pemasyarakatan yang berupa pembekalan pendidikan formal dan nonformal berupa keahlian atau keterampilan yang dapat digunakan sebagai bekal wirausaha dalam kehidupan bermasyarakat. Dalam hal ini, anak didik lembaga pemasyarakatan yang memiliki kesiapan yang baik diharapkan dapat mengetahui norma dan etika dalam kehidupan bermasyarakat serta memiliki perencanaan hidup sehingga ketika keluar dari lembaga pemasyarakatan anak, anak didik lembaga pemasyarakatan dapat termotivasi kembali untuk beraktivitas sebagai warga negara yang baik dan bertanggungjawab.

\section{Petugas}

Petugas lembaga pemasyarakatan anak memiliki peran yang penting dalam upaya membina anak didik lembaga pemasyarakatan sesuai dengan tujuan dari setiap tahap pembinaan. Petugas diharapkan dapat mengetahui perkembangan setiap anak didik lembaga pemasyarakatan untuk setiap bagian tahap pembinaan berdasarkan hasil peninjauan dari catatan di kartu pembinaan oleh wali pemasyarakatan anak.

Hasil dari pencatataan pada kartu pembinaan dapat menjadi dasar dari perencanaan pembinaan pada tahap selanjutnya sesuai dengan kebutuhan dan permasalahan anak yang ada. Seiter, Kadela (2003) mengemukakan bahwa salah satu hal yang perlu diperhatikan adalah program reintegrasi yang memungkinkan bagi mantan narapidana anak untuk kembali ke kehidupan bermasyarakat atas dasar pengalaman dirinya dari hasil pembinaan di Lembaga Pemasyarakatan Anak. Pembinaan yang ada di Lembaga Pemasyarakatan Anak difokuskan menjadi tiga fungsi pembinaan sebagai bentuk pembinaan mental, fisik, dan sosial (Gultom, 2008).

\section{HASIL DAN PEMBAHASAN}

Kesiapan Fisik, Mental, dan Sosial Anak Didik Lembaga Pemasyarakatan
Menurut Kamus Besar Bahasa Indonesia, kesiapan adalah suatu keadaan bersiap-siap untuk mempersiapkan sesuatu. Hal ini juga didukung oleh Dalyono (2005), bahwa kesiapan adalah kemampuan yang cukup baik fisik dan mental untuk melakukan suatu kegiatan. Namun, bukan hanya kesiapan mental, Oemar Hamalik (2008) mengemukakan bahwa kesiapan juga merupakan tingkatan atau keadaan yang harus dicapai dalam proses perkembangan perorangan pada tingkatan pertumbuhan mental, fisik, sosial dan emosional.

Berdasarkan kepada definisi di atas, maka peneliti menyimpulkan bahwa kesiapan dapat diartikan sebagai suatu keadaan atau kemampuan yang baik, baik secara fisik, mental, maupun sosial untuk melakukan suatu kegiatan atau kerja. Kesiapan seorang anak didik lapas juga akan dipengaruhi oleh pengalaman menjalani proses pembinaan selama masa tahanan di Lembaga Pemasyarakatan Anak. Menurut Gultom (2008), pembinaan yang dilakukan di Lembaga Pemasyarakatan Anak difokuskan pada pembinaan fisik, mental, dan sosial. Berbagai pengalaman diri akan membentuk pandangan dirinya terhadap lingkungan fisik dan sosial di sekitarnya. Mantan narapidana anak sebagai seorang remaja memiliki hak akan pemenuhan kebutuhan di tengah kehidupan bermasyarakat.

Dalam sebuah penelitian di United States Department of Labor dengan karya yang berjudul Center for Faith-Based and Community Initiatives, dikemukakan bahwa salah satu hal yang menghambat kesuksesan mantan narapidana dalam menghadapi proses integrasi ke dalam masyarakat adalah ketidakpercayaan masyarakat terhadap mantan narapidana akan status yang disandangnya sehingga diperlukan suatu program reintegrasi bagi mantan narapidana dalam melakukan proses sosialisasi kembali dengan baik dalam kehidupan bermasyarakat. Hal ini akan terkait dengan upaya pemenuhan kebutuhan dan hak bagi mantan narapidana anak untuk kembali dalam kehidupan bermasyarakat. Kesiapan 
anak didik lapas dalam menghadapi proses integrasi ke dalam masyarakat akan terkait dengan program asimilasi yang diadakan sebagai upaya reintegrasi kembali anak didik lapas dalam kehidupan bermasyarakat. Program reintegrasi bagi anak didik lapas akan didapatkan selama menjalani proses pembinaan pada 2/3-1/3 sisa masa tahanan. Atas dasar penelaahan lebih lanjut, maka Kvawarceus (1964) dalam karyanya di Unesco yang berjudul Juvenile Delinquency A Problem For the Modern World, mengemukakan bahwa seharusnya penanganan mantan narapidana anak difokuskan pada reintegrasi dirinya dalam kehidupan bermasyarakat dan pengakuan bahwa kasus kenakalan remaja merupakan bagian tanggungjawab dari masyarakat akan usaha pencegahan dan pengawasan terhadap terjadinya kejahatan.

\section{$\underline{\text { Kesiapan Fisik }}$}

Kesiapan fisik bagi anak didik lapas dapat diartikan sebagai suatu keadaan siap untuk melakukan aktivitas dengan kesehatan fisik dalam keadaan baik, dalam arti kondisi fisik yang sehat dan secara klinis juga tidak dinyatakan mengalami suatu penyakit atau gangguan fungsi tubuh. Anak didik lapas yang memiliki kesiapan fisik dengan kondisi jasmani yang baik akan menjadi salah satu faktor pendukung keberhasilan dirinya untuk berintegrasi kembali dalam kehidupan bermasyarakat. Hal ini dikarenakan bila anak didik lapas mengemukakan kesiapan fisik dirinya dalam kondisi yang baik, maka anak didik lapas tersebut dapat menggunakan seluruh kemampuan dan fungsi tubuhnya untuk beraktivitas kembali secara optimal.

\section{Kesiapan Mental}

Kesiapan mental anak didik lapas akan terkait dengan pembinaan mental yang dilakukan oleh Lembaga Pemasyarakatan Anak. Kesiapan mental bagi mantan narapidana anak akan terkait dengan keadaan psikososial diri anak akan pemikiran dan perasaan dirinya dalam upaya untuk mengontrol kembali tingkah lakunya secara tepat. Anak didik lapas diharapkan sudah menyadari kesalahan dan bisa menerima serta menangani rasa frustasi dengan wajar, mengendalikan emosi dirinya melalui ibadah (agama), memiliki rasa kepercayaan diri dan semangat untuk kembali ke kehidupan bermasyarakat, dan dapat menangani rasa emas dan gelisah.

\section{Kesiapan Sosial}

Kesiapan sosial bagi anak didik lapas dapat diartikan sebagai suatu kondisi dimana anak didik lapas sudah siap melakukan aktivitas kembali dalam kehidupan bermasyarakat dengan mengetahui norma-norma agama, kesusilaan, etika pergaulan dan pertemuan dengan keluarga atau kerabat, dan pengetahuan akan hidup bermasyarakat yang baik. Hal ini akan dipengaruhi oleh program pembinaan yang dijalankan di Lembaga Pemasyarakatan Anak terkait dengan pembinaan sosial. Pembinaan sosial akan terkait pula dengan adanya kesempatan bagi anak didik lapas untuk mengadakan hubungan komunikasi dengan keluarga melalui kunjungan atau media surat serta penerimaan akan pelatihan maupun penyuluhan mengenai bimbingan kemasyarakatan.

Analisis Kebutuhan Sosialisasi Bagi Mantan Narapidana Anak

Menyandang status sebagai mantan narapidana anak memberikan dampak terhadap aksesibilitas pemenuhan hak dan kebutuhan dirinya sebagai seorang remaja. Terlebih bila hal ini tidak didukung dengan kemampuan dirinya untuk mengaplikasikan apa yang telah dipelajarinya selama memperoleh proses pembinaan di Lembaga Pemasyarakatan Anak.

Berdasarkan hasil penelitian Artyawan (2013), penyelenggaraan program pendidikan keterampilan di Lembaga Pemasyarakatan memberikan kontribusi terhadap kesiapan narapidana kembali ke masyarakat hanya sebesar 44,7\%. Pembinaan fisik, sosial, dan mental di Lembaga Pemasyarakatan Anak belum berfungsi secara optimal dalam memberikan kepercayaan diri bagi mantan narapidana anak dalam menghadapi proses integrasi ke dalam masyarakat. Hal ini 
menunjukkan bahwa mantan narapidana anak membutuhkan binaan kembali setelah keluar dari Lembaga Pemasyarakatan Anak sebagai salah satu upaya untuk mengembalikan kepercayaan dirinya bersosialisasi kembali dalam kehidupan bermasyarakat.

Salah satu hal yang perlu diperhatikan kiranya bagi mantan narapidana anak adalah keberlanjutan pendidikan formal. Kesetaraan dalam mendapatkan hak pendidikan bagi setiap anak di dunia menjadi fokus perhatian pada Konferensi UNESCO bulan November 2014 lalu. Menurut Shimomura, Minister of Education, Culture, Sports, Science, and Technology Japan dalam penyampaiannya di UNESCO WORLD CONFERENCE ON Education for Sustainable Development (2014), mengemukakan bahwa pendidikan merupakan rangkaian aktivitas untuk membangun masa depan dengan tujuan pembangunan berkelanjutan dalam meningkatkan kesejahteraan individu dan masyarakat atas dasar nilai dan norma yang berlaku. Mantan narapidana anak merupakan salah satu bagian masyarakat yang terhambat aksesibilitas hak dan kebutuhannya. Bila meninjau akan advokasi kesetaraan hak akan pendidikan, maka binaan akan pendidikan formal dan nonformal dapat menjadi salah satu bentuk upaya preventif dalam menangani mantan narapidana anak dari kemungkinan terjadinya kasus residivis.

Aksesibilitas yang minim terhadap pemenuhan hak dan kebutuhan bagi mantan narapidana anak sebagai seorang warga negara merupakan salah satu dampak dari ketidakberdayaan masyarakat dalam memberikan kepercayaan kembali kepada mantan narapidana anak untuk menjalankan perannya sebagai seorang remaja dan warga negara. Begitupula dengan terbatasnya frekuensi waktu dan tempat kunjungan bagi anak didik lapas dan keluarga di Lembaga Pemasyarakatan Anak memberikan dampak negatif terhadap kualitas hubungan dirinya dan keluarga. Menurut Seiter, Kadela dalam sebuah penelitian yang berjudul Prisoner Reentry: What Works, What Does Not, and What Is Promising (2003), mengemukakan bahwa hal utama yang perlu diperhatikan dari keberadaan mantan narapidana adalah adanya pengawasan dari masyarakat dalam bentuk stabilitas dukungan dan pelayanan sosial yang khusus diberikan kepadanya dalam bentuk program ataupun aktivitas yang memungkinkan mantan narapidana tidak menjadi residivis.

Atas dasar fenomena tersebut, maka dapat diketahui bahwa diperlukan suatu upaya restoratif, baik dalam bentuk kuratif maupun rehabilitatif dalam menangani mantan narapidana anak yang tidak berdaya dalam menghadapi penolakan masyarakat atas keberadaan dirinya. Salah satu upaya penanganan pemenuhan hak dan kebutuhan dengan lingkungan sosial yang mendukung adalah reunifikasi keluarga dan masyarakat.

\section{SIMPULAN}

Kasus residivis anak terjadi sebagai akibat dari rendahnya kesiapan anak didik lapas dalam menghadapi proses integrasi ke dalam masyarakat selepas keluar dari Lembaga Pemasyarakatan Anak. Kesiapan bagi anak didik lembaga pemasyarakatan terkait dengan pembinaan yang diadakan oleh Lembaga Pemasyarakatan Anak adalah kesiapan fisik, mental, dan sosial. Penyebab dari rendahnya kesiapan anak didik lapas tersebut dikarenakan pembinaan di Lembaga Pemasyarakatan Anak yang kurang efektif dan tidak terintegrasi dalam kehidupan bermasyarakat. Kesiapan anak didik lapas akan terkait dengan proses pembinaan yang dijalankan dalam program asimilasi.

Kebutuhan anak didik lembaga pemasyarakatan dalam kehidupan bermasyarakat diantaranya adalah kebutuhan sosialisasi yang memungkinkan dirinya untuk mendapatkan kembali pemenuhan hak dan kebutuhan sebagai seorang warga negara. Penanganan kebutuhan sosialisasi bagi anak didik lembaga pemasyarakatan dapat dimediasi dengan peninjauan ulang program pembinaan di Lembaga Pemasyarakatan Anak melalui revitalisasi kebijakan program 
sehingga fokus pada reintegrasi anak didik lapas selepas menjalani masa pembebasan maupun melalui pengadaan lembaga pemenuhan kebutuhan sosialisasi bagi mantan narapidana anak dengan fokus pada reintegrasi anak dalam kehidupan bermasyarakat.

\section{SARAN}

Pembinaan di Lembaga Pemasyarakatan Anak sebaiknya difokuskan terhadap revitalisasi program asimilasi dengan fokus tujuan pada reintegrasi narapidana anak dalam masyarakat serta memperhatikan kualitas dan frekuensi kunjungan keluarga sebagai salah satu upaya preventif dalam menangani kasus residivis bagi mantan narapidana anak. Hal ini mengingat akan pentingnya penanganan secara preventif dan restoratif mengingat akan rendahnya kesiapan anak didik lapas oleh karena pembinaan di Lembaga Pemasyarakatan Anak yang kurang efektif, sehingga diharapkan dapat meminimalisir terjadinya kasus residivis anak setelah menjalani masa pembebasan dari Lembaga Pemasyarakatan Anak. Revitalisasi program asimilasi bagi anak didik lapas merupakan salah satu upaya mengefektifkan peran Balai Pemasyarakatan Anak dalam meninjau perkembangan dan melakukan pengawasan sosial terhadap keberadaan anak selepas keluar dari lapas.

\section{DAFTAR PUSTAKA}

Artyawan, Adetyo, Januari 2013, "Pengaruh Program Pendidikan Keterampilan Terhadap

Kesiapan Narapidana Kembali ke Masyarakat", NFECE 2 (1) (2013), hlm. 55

Direktorat Jenderal Pemasyarakatan. 2015. Sistem Database Pemasyarakatan. http://smslap.ditjenpas.go.id/public/grl/current /monthly (diakses pada tanggal 21 Maret 2015)

Gultom, Maidin. 2008. Perlindungan Hukum terhadap Anak dalam Sistem Peradilan Anak

Pidana di Indonesia. Bandung: PT Refika Aditama

Marlina. 2009. Peradilan Pidana Anak di Indonesia: Pengembangan Konsep Diversi dan

Restorative Justice. Bandung: PT.Refika Aditama

Loeber, Rolf, dkk. 2013. From Juvenile Delinquency to Young Adult Offending. Melalui, < https://ncjrs.gov/pdffiles1/nij/grants/ 242931.pdf $>$ [8/5/15]

Seiter, Richard P., Kadela, Karen R. 2003. Prisoner Reentry: What Works, What Does Not, and

What Is Promising. Hlm 361-362

Gelb, Adam, dkk. 2014. The Pew Charitable Trusts: The Rise in Prison Inmates Released Without Supervision

Alexander, Michelle. 2013. A Second Chance: Charting a New Course for Re-Entry and

Criminal Justice Reform. The Leadership Conference Education Fund

Kartono, Kartini. 1981. Patologi Sosial. Jakarta: CV Rajawali

Anderson, E. (1990). Streetwise: Race, class, and

change in an urban community. Chicago: University of Chicago Press 